\title{
Research on the Effective Management of Examination Reform
}

\author{
Tian Zhang1, Man Liu², Zhuangwang Zang3 \\ ${ }^{1}$ Training Department, Air Force Logistics College, Xuzhou, China \\ ${ }^{2}$ Department of Basic Courses, Air Force Logistics College, Xuzhou, China \\ ${ }^{3}$ Department of Military Supplies, Air Force Logistics College, Xuzhou, China \\ Email: liuman8866@163.com
}

Received 2 September 2014; revised 6 October 2014; accepted 20 October 2014

Copyright (C) 2014 by authors and Scientific Research Publishing Inc.

This work is licensed under the Creative Commons Attribution International License (CC BY). http://creativecommons.org/licenses/by/4.0/

(c) $\underset{\mathrm{EY}}{\mathrm{i}}$ Open Access

\begin{abstract}
Based on the scientific development concept of examination management, we establish an efficient, standardized examination management system, and build up the scientific and reasonable examination appraisement system. It can promote the learning and teaching through examination, and make the "test", "teaching" and "learning" harmonious and unified, to push forward the effective management reform of college examination.
\end{abstract}

\section{Keywords}

Examination Management System, Evaluation System, Effective Management

\section{Introduction}

Examination as a form of testing is often used in teaching [1]-[6]. It is not only to assess the students' academic performance, help and urge students to systematically master the knowledge and skills, but also to check the teaching effect and promote teachers to improve the teaching work. The examination reform in colleges and universities has been carried out for many years, and has made some progress. But still there has been no substantive breakthrough. Examination reform becomes a mere formality. Ignoring the management of the examination reform is the important factor which cannot be ignored. To change this situation, it is necessary for the department and personnel of management to effectively manage the examination reform.

\section{Efficient and Standardized Examination Management System}

The core of examination management is to reform effectively and develop scientifically, through scientific management, "people-oriented” education philosophy, changing the testing present situation, to provide a plat- 
form and base for students to develop all-round. For scientific examination management it is necessary to emancipate the mind, follow the rules of education teaching, bold practice, have the courage to explore, pay attention to the effect and efficiency of management.

\subsection{Innovating the Content of the Examination Management System}

Efficient and standardized examination management system is the premise condition to ensure that the exam reform is going on smoothly in college, for examination management system it includes the perpetrators and receiver. Teaching management, the secondary school (department) and the teachers are the implementer in examination organization, the main contents include the exam concept, the regulations for the test work, The feedback and improvement of test and the reward safeguard mechanism of exam reform.

\subsubsection{Examination Concept}

Examination concept is the key to set up on the basis of the test to promote teaching reform, recognize the importance of the examination, it not only plays a strong guiding role on education activity, but also evaluate and improve the teaching as the basic way to cultivate innovative talents; At the same time it is an important means of guiding students to learn actively and creatively; It is an important segment to test and improve students' innovative thinking and innovative ability. Scientific and reasonable, encouraging innovation and dynamic test is helpful to improve teaching effect and teaching quality, cultivate students' creativity, promote the students' autonomous learning ability of ascension, ultimately teaching and learning are interactive, mutual harmony into each other.

\subsubsection{The Regulations of Exam Management}

The key is to strengthen the producing papers, printing, confidentiality, and security management, testing organization, marking exam papers, reading scores, analyzing examination paper, binding, archiving, being in the charge of the examination, touring test and the various links of responsibilities such as routine management. It needs to emphasize: 1) In the proposition of examination paper it is advocated in the classified guidance, examination database should be constructed scientifically. According to the different teaching content adjust database in time; after fine-tuning forming the test with volume at random; 2) Organization of the exam. In view of the different ways of examination reform, according to the mode and characteristics of examination, choice the corresponding management. Especially in the current case, the network teaching platform has been established basically, cooperative education is further improved, the teaching mode reform in the classroom continuously strengthen, in a certain area, of intercollegiate between online test, group discussion, and school internship diary, the learning (experience) equalization and combining qualitative way of formative assessment. Through the homework in the class, class discussion, classroom questioning, classroom tests, and so on, by the ways to understand the students' master degree, teachers, students, social development main body evaluation, to achieve higher education park between the mutual recognition of credits and the teaching resources sharing. This is not only beneficial to the higher level to develop a high level of curriculum resources, but also to improve the education resource utilized efficiently.

\subsubsection{The Feedback and Improvement of Test}

The key is to play a role of examination for the teaching process to examine and promote actively, the feedback value and improvement of the test. American educator, Scriven M. believed that teachers' basic professional responsibilities include nine aspects, there are three aspects related to the test: one is for students to learn to collect formation, for teachers to compile, select, and manage appropriate tests, to give students and management departments to provide information on students' progress; Second is to score; Three is to avoid deviation in the process of grading in possible extent. Led by the United States education evaluation and curriculum theory expert Taylor's "review committee" in 1942, put forward the idea of education evaluation, think it should replace the test with education evaluation. He advocated the education evaluation is to measure the extent of the actual education activities to achieve education goals, and find out the practical activity and the education target, through the information feedback, promote education activities as much as possible to achieve education target. An important concept of modern education assessment is "evaluation is not to prove but to improve". Through the evaluation system, the teacher should be able to understand the situation of the students, timely find the problems existing in the teaching process, the first time to reflect on the teaching method, guide students to im- 
prove methods of learning, teachers and students together amend teaching process; Then evaluate, revise, interact recursively, establish "the goal, process, evaluation, feedback and correction" into each other between teaching and learning mode, by test driving the course teaching reform. Therefore, evaluation should not only focus on students' academic performance, but also discover and develop the potential of the students, understand the requirements in the development of students, help students to understand the self, establish self-confidence, play the education function of evaluation, promote the development of students at the original level.

\subsubsection{The Reward Security System of Examination Reform}

It should fully embody the dominant position of teachers in the examination reform, for the examination paper, subsidies invigilation, examines to correspond teaching workload (suggest 4 classes teaching workload), to give a reward for test method or the reform of evaluation standard effectively; It is needed to provide all kinds of places for examination reform, equipment and other hardware facilities, special examination reform teaching research funds, is used in the investigation, study and solving the problem in the examination reform. The examination receivers are students, the contents of corresponding system are mainly about measures to prevent students cheating on the examination. In recent years, college students' cheating in examinations has become one of the most serious problems in the management of teaching, which not only deviate from the aim of education, deviate from the aim of examination, influence the improvement of teaching quality, interfere the credibility of teaching quality assessment, but also add to the bad habits of the students, block the formation of good style of study and school spirit. Therefore, to prevent students cheating on the examination has become one of the important content of examination reform needed to study.

\subsection{The Publicity, Implementation and Execution of System}

Propaganda and implementation are the two important links to ensure that system is carried out well. Except through the campus media such as newspapers, radio, websites to enhance the promotion of exam further, can also by writing books related publicity, manuals, etc., compile the related management system, documents and other relevant content, so it is advantageous for the related personnel to understand the examination management comprehensively. The key of system construction is the execution. The execution is the starting point and ultimate end-result of system. During the implementation of reform of examination management system it should pay attention to the sustainability in particular, at present this is an important factor caused that the effect of examination reform was not significant. The key of construction of examination management system is continuous, it requires the supervision and feedback of management department and the examinee, it needs a selfcorrecting and improve continuously. The reason is that the adjustment of content, the reform of examination management, the change of the way of test, all put forward the adaptability of system, so it needs to further improve the management department according to the actual situation.

\section{Scientific and Reasonable Evaluation System of Examination Management}

At present, The evaluation of examination management in colleges and universities is out of control, how about the quality of the exam management is no one concern, have no the corresponding evaluation criteria. To build scientific and reasonable evaluation system for the examination management, to test the proposition, confidential security, organization arrangement, reading over and giving marks, recording scores, binding the examination paper, preservation and so on, check every link and evaluate, it is important to ensure that the examination reform is effective, the management is standard, the quality is improved.

1) The index of evaluation system. In the management of examination reform, the evaluation systems of college exam management have been established, it can not only focus on the quality of evaluation, but also attach great importance to the teaching process; Both focus on academic tests and the students' development; Give full play to the educational function of subject teaching, promote the full implementation of the school examination reform management. Indexes of the system are set up class 5, 16 secondary index and main observation point to 40, covering from paper proposition to the archive file and so on. Primary index contains papers proposition, confidential security, organizing, marking examination papers, reading scores and binding, all together are five aspects. The secondary indicators include thesis basis, the thesis examination scope, mode and database construction, proposition secrecy and papers, the exam discipline to prevent, examination arrangements, supervise, cruise and exam summary and evaluation, reading group evaluation specification, performance and achieve- 
ments recorded, binding test paper, and save, all are total 16. Each secondary index contains series of observation points, to evaluate the whole process of test.

2) The implementation of evaluation. Establishing diversified appraisal system of the examination management, changing the single college evaluation for teaching management department, the department, teaching and research section, the experts, teachers and students and so on participate widely, parties are involved in the multi-agent evaluation, improve the effect of evaluation. College is responsible for all kinds of management of the college exam evaluation; According to the corresponding secondary index department, research section, teachers and students are in charge of the evaluation indicators.

The results of evaluation are linked with the assessment training of school, the ultimate goal of evaluation is "by appraising to build, by appraising to manage", for the problems found during the evaluation process must be corrected and improved timely, gradually standardize the examination management. Both management and teachers, all should pay great attention to the summary and evaluation of examination. The department of management should focus on the summary and evaluation of specifications, business training, service awareness, the teachers should focus on the summary and evaluation of examination proposition, test mode, distribution of the achievement, problems and improvement. In particular, it should emphasize on the exam evaluation of course, according to the requirements of teaching outline and the distribution of students' scores and the practical situation of students, teachers should analyze carefully, and through the classroom evaluation or individual evaluation feedback to students, make students know what is he fail to grasp, adjust the way and methods of study, so that the teachers' teaching and students learning are together improved.

\section{Conclusion}

Higher education mainly involves "teaching” "learning” and "testing”. "Teaching” is the foundation; "learning” is the guarantee; "testing" is the intermediary. The three aspects are indispensable, linked to each other and dialectical unity. Using the effective management of examination reform can strengthen the system construction. It helps us to understand the importance, purpose and function of the examination, and can change the teachers' and students' concept on examination. Building the appraisal system of examination can supervise the whole process. Eventually, it guides the students to study actively and creatively, by "testing" to teach, by "testing" to learn. So we should let "testing”, "teaching” and "learning” be unified effectively.

\section{References}

[1] Liu, N. and Dong, X. (2008) Research on the Reform and Security of College Examination. Journal of Shenyang Architectural University.

[2] Wang, L. and Liu, H.-Y. (2006) Analysis on the Restrict of College Examination Reform. Higher Engineering Education Research.

[3] Han, S.-J. (2011) The Exploration of Evaluation Mode in the High Professional University. Education and Profession, 29, 166-167.

[4] Li, X.-Q. and Shu, H. (2011) The Exploration and Practice of Examination Model Reformed by Stratified Teaching in Higher Vocational Mathematics Curriculum. Journal of Chifeng University, 9, 252-253.

[5] Niu, W.-X. (2000) Quality Education Calls for the Examination Reform. Education of Naval Academies, 3, 73-74.

[6] Zhao, J.-Z. (2010) The Research on the Present Situation of the Examination Reform in Higher Vocational Colleges. Chinese Examination, 7, 40-44. 
Scientific Research Publishing (SCIRP) is one of the largest Open Access journal publishers. It is currently publishing more than 200 open access, online, peer-reviewed journals covering a wide range of academic disciplines. SCIRP serves the worldwide academic communities and contributes to the progress and application of science with its publication.

Other selected journals from SCIRP are listed as below. Submit your manuscript to us via either submit@scirp.org or Online Submission Portal.
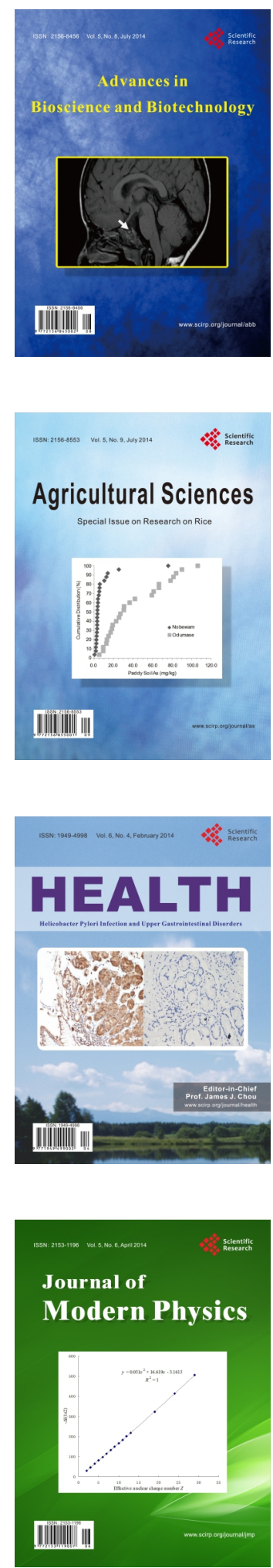
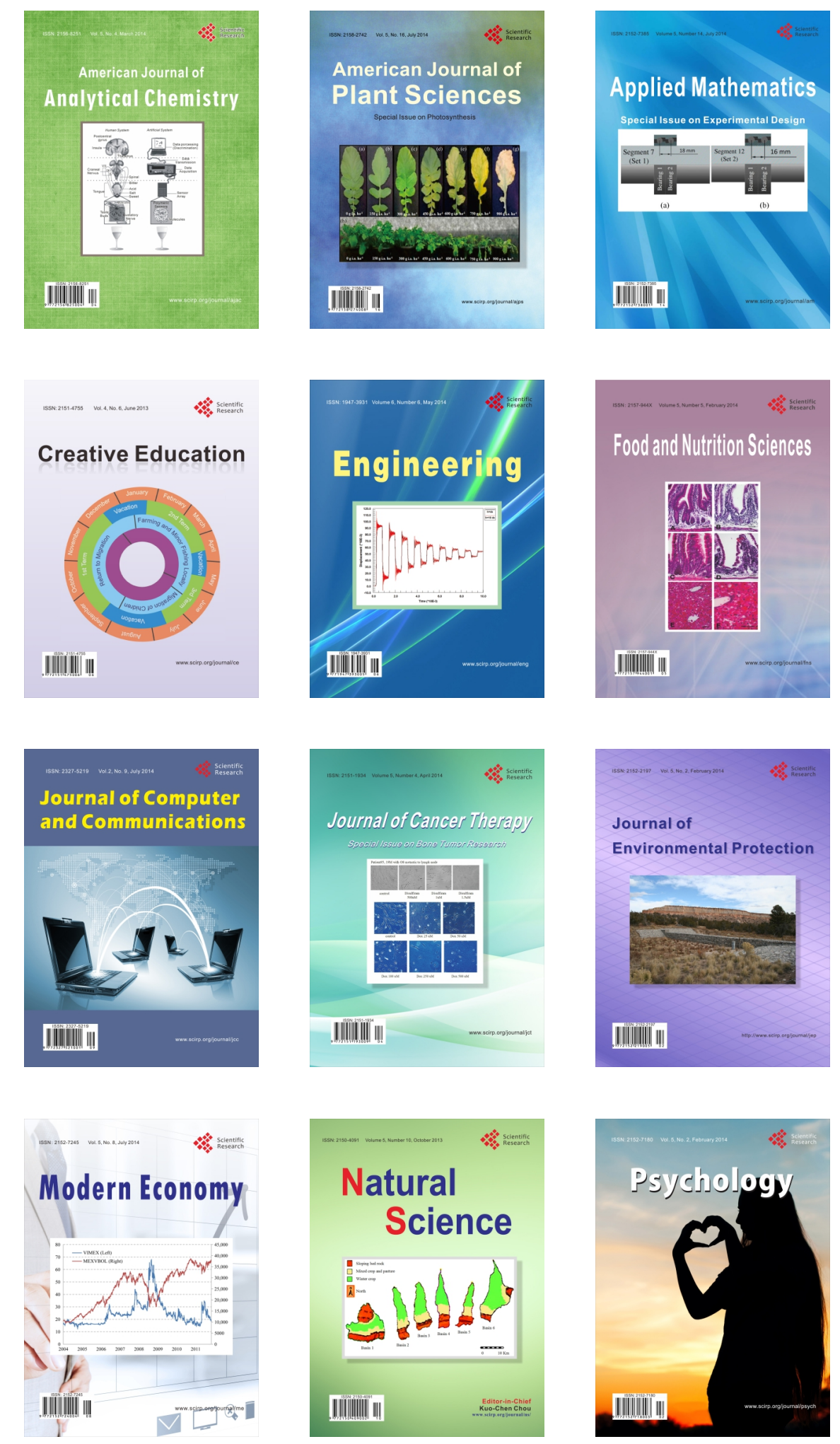